\title{
Zastosowanie metody QFD w projektowaniu usług rekreacyjnych
}

\author{
Autorzy: Anna Szeliga-Kowalczyk, Anna Łabaza
}

\begin{abstract}
Abstrakt
Celem artykułu jest przedstawienie możliwości zastosowania metody Quality Function Deployment (QFD) w projektowaniu usług rekreacyjnych. Metoda QFD jest doskonałym narzędziem projektowania i przygotowania usługi w sposób umożliwiający uniknięcie niezgodności w trakcie jej dostarczania, a także uwzględnienia wymagań klienta. Wykorzystanie tej metody pozwala uzyskać opinię klienta, zanim usługa zacznie być świadczona, zatem pozwala usługodawcy zabezpieczyć się przed ewentualnym niezadowoleniem, a w konsekwencji roszczeniami i utratą klienta. Jako metodę badawczą zastosowano analizę literatury przedmiotu oraz opis studium przypadku. Dotychczas metoda QFD wykorzystywana była głównie w projektowaniu wyrobów oraz procesach produkcyjnych. Możliwości jej zastosowania w usługach są również bardzo duże, zaś jej użyteczność z punktu widzenia potencjalnych korzyści bardzo wysoka. W rozdziale pierwszym artykułu zaprezentowano specyfikę usługi rekreacyjnej, jej cechy i czynniki warunkujące odpowiednie przygotowanie, jak również podstawowe formy dostarczania tego rodzaju usług. Rozdział drugi zawiera szczegółową charakterystykę i opis metody QFD. W rozdziale trzecim zaprezentowano praktyczny przykład wykorzystania tej metody w projektowaniu wybranej usługi rekreacyjnej.
\end{abstract}

Słowa kluczowe: rekreacja, usługa, jakość, projektowanie, klient, doskonalenie, funkcja jakości, QFD

JEL: L8, L83, L15

\section{Wstęp}

Troska o dobro i trwałe relacje $\mathrm{z}$ klientem to jeden z podstawowych czynników o charakterze niematerialnym, które stanowią impuls do rozwoju
Historia: otrzymano 2015-09-08, poprawiono 2016-05-12, zaakceptowano 2016-05-12

organizacji usługowych, a także wzrostu ich wartości. Zasadnicza przesłanka budowy pozytywnych relacji klienta z organizacją to zaspokojenie jego wymagań i oczekiwań przez świadczenie usług na wysokim poziomie. Jakość 
staje się coraz częściej jedną z podstawowych determinant warunkujących decyzje zakupowe klienta (Skrzypek 2009).

W obecnym czasie przywiązuje się znaczną uwagę do takich wartości, jak zdrowie, młodość, kondycja fizyczna, odpowiedni wygląd itp. Wykorzystuje się do tego szeroki wachlarz możliwości uzyskania dobrego samopoczucia, które jest niezbędne do prawidłowego funkcjonowania jednostki. Jakość usług rekreacyjnych staje się jednym z kluczowych czynników mających wpływ na jakość życia. Udział usług rekreacyjnych w kształtowaniu jakości życia ma coraz większe znaczenie (Goranczewski, Puciato 2009: 4-9).

Dynamicznie rozwijający się rynek stawia coraz wyższe i restrykcyjne wymagania. O sukcesie organizacji usługowej świadczy wolumen sprzedaży oferowanych usług. Istotne jest zatem, aby usługa była zgodna z wymaganiami klientów. Kluczowego znaczenia nabiera konieczność:

- zaprojektowania i wprowadzenia usługi odpowiadającej gustom i oczekiwaniom klientów, a także

- przygotowania jej w taki w sposób, aby nie występowała dychotomia między projektem a sposobem realizacji usługi.

Przedsiębiorstwa muszą zapewnić swoim usługom jakość zgodną z oczekiwaniami klienta. Niejednokrotnie trudno jest zinterpretować ogólne i mało konkretne oczekiwania klienta tak, aby na ich podstawie móc zaprojektować satysfakcjonujący go produkt czy usługę. Ważną rolę $w$ tym procesie odgrywa umiejętność przetwarzania i interpretacji danych na etapie projektowania usługi. Właściwą jakość może mieć tylko usługa prawidłowo zaprojektowana oraz dostarczona w procesach gwarantujących uzyskanie założonych parametrów projektowych.

Celem niniejszego artykułu jest zaprezentowanie metody QFD nazywanej metodą projektowania $\mathrm{z}$ udziałem klienta. Najczęściej jest ona wykorzystywana w projektowaniu i produkcji wyrobów. Opisywany w artykule przykład pokazuje możliwość zastosowania tej metody również w projektowaniu i realizacji usługi rekreacyjnej, jaką jest nauka jazdy na nartach. W artykule wykorzystano takie metody, jak analiza literatury przedmiotu oraz opis studium przypadku zastosowania metody QFD w projektowaniu usługi rekreacyjnej (Czakon 2013: 92 i n.).

\section{Specyfika usług rekreacyjnych}

We współczesnej gospodarce rynkowej jakość usługi jest dominującą determinantą warunkującą dokonanie transakcji zakupu. W przypadku niedotrzymania jakości w trakcie trwania usługi następuje utrata zaufania do organizacji, rozczarowanie, a $\mathrm{w}$ efekcie odejście klienta do konkurencji (Maciąg 2011: 9).

Oferta usługi rekreacyjnej zawiera najczęściej komponenty materialne (infrastruktura) oraz niematerialne (np. wiedza trenera). Stanowi zatem dobro mieszane (Kotler 1996). Obecnie obserwowane jest zjawisko zacierania się jednoznacznej granicy między usługą a produktem. Większość ofert rynkowych to kompilacja (mieszanka) produktów i usług.

Do cech charakterystycznych, warunkujących powodzenie realizacji usługi można zaliczyć (Czubała 2006: 13):

- niematerialność - usługa istnieje w sferze wyobrażenia, zatem ważne jest, aby to wyobrażenie było jak najbardziej zbliżone do rzeczywistości;

- nietrwałość - dana usługa jest przemijająca, co oznacza, że nie można jej odtworzyć/powtórzyć; raz niewykorzystana przepada, a wraz z nią powstają negatywne skutki ekonomiczne w postaci poniesionej straty;

- nierozdzielność dostarczania i konsumpcji - oznacza, że realizacja 
usługi odbywa się w miejscu i czasie jej świadczenia; przygotowanie usługi winno zagwarantować integralność dostarczania i konsumpcji w sposób umożliwiający uzyskanie zadowolenia klienta;

- nierozdzielność usługi i wykonawcy - usługa jest realizowana w czasie rzeczywistym, a zatem błędy $w$ projekcie czy $w$ realizacji/dostarczaniu mogą nie być możliwe do skorygowania.

- Usługa rekreacyjna może być świadczona w formie (Gospodarek 2008: 43 i n.):

- usługi indywidualnej, realizowanej na rzecz jednego odbiorcy, np. indywidualna nauka pływania, ćwiczenie z osobistym trenerem;

- usługi zespołowej, w postaci np. gry ruchowej, ćwiczeń gimnastycznych;

- imprezy rekreacyjnej w postaci festynu, spartakiady, konkursu, ligi rekreacyjnej, wycieczki, rajdu, biegu przełajowego, imprezy narciarskiej itp. (Maciąg 2011: 23).

\section{Charakterystyka metody QFD}

QFD to metoda, której celem jest przeniesienie potrzeb i oczekiwań klientów na charakterystykę usługi. W języku polskim tłumaczona jest jako rozwinięcie funkcji jakości. Zaczęto jej używać od 1972 r., pierwotnie w Japonii, głównie w przemyśle stoczniowym. Po sukcesach, jakie przyniosło jej stosowanie, zaczęła być popularna także w Stanach Zjednoczonych. Obecnie wykorzystywana jest w przemyśle motoryzacyjnym, IT, elektronicznym itp. Coraz większe znaczenie odgrywa także w projektowaniu usług. Dyfuzja przedmiotowa metody jest znacznie szersza i oprócz wspomnianego projektowania czy dostarczania usługi, które zajmują pierwsze miejsce $\mathrm{w}$ zastosowaniach, obejmuje również takie aktywności, jak planowanie, rozwój, badania zaopatrzenie, marketing, sprzedaż (Ćwiklicki, Obora 2008: 4-7).
W metodzie QFD łączy się wymagania użytkowników nie mających często świadomości możliwych do zastosowania rozwiązań technicznych z wiedzą inżynierską/projektancką, która w oparciu o znajomość oczekiwań klienta wykorzystywana jest do zaprojektowania i/lub dostarczenia usługi najbardziej zbliżonej do tych oczekiwań. Usługobiorca nie musi znać ostatecznych możliwości realizacji usługi oraz potencjalnych dodatkowych efektów z nich wynikających. Ma jednak sprecyzowane oczekiwania, które artykułuje językiem klienta, niejednokrotnie odbiegającym od języka technicznego, którym posługuje się projektant. W przypadku rekreacji projektant usługi musi znać oczekiwania klienta, które w zestawieniu z jego wiedzą specjalistyczną mają doprowadzić do osiągnięcia najwyższej jakości usługi (Goranczewski, Szeliga-Kowalczyk 2015). Na przykład żeglowanie, jak każda forma aktywności, jest doskonałym źródłem rekreacji. Jednocześnie jest źródłem prestiżu. Zatem projektowanie tego typu usług musi być oparte na wymaganiach i oczekiwaniach klienta, które często są jeszcze przez niego nierozpoznane/ nieuświadomione. $W$ procesie tym w organizacji, która dostarcza usługi rekreacyjne, uczestniczą specjaliści, m.in.:

- $\quad$ specjalista ds. marketingu - badający rynek, w tym potrzeby i oczekiwania klientów,

- projektant - projektujący usługi, posiadający wyspecjalizowaną wiedzę w zakresie określonego pakietu usług, jednocześnie nie posiadający wystarczającej wiedzy rynkowej,

- technolog/metodyk - wdrażający metody bądź sposoby dostarczania usługi.

Wszystkie podmioty uczestniczące $w$ realizacji usługi muszą dokonywać szeregu konsultacji i uzgodnień, co niejednokrotnie powoduje 
zniekształcenia informacyjne. Metoda QFD porządkuje te kwestie, wychodząc naprzeciw oczekiwaniom wszystkich stron zainteresowanych tym, żeby ich wymagania były uwzględnione. Z tego powodu metoda QFD nazywana jest metodą sterowania jakością przez klienta (Zymonik, Wąsińska 2007). Wykorzystywana jest jako narzędzie przetransponowania informacji rynkowych, przekazywanych terminologią wykorzystywaną przez klientów na język techniczny. Stąd też QFD opisywana jest jako metoda projektowania z udziałem klientów (Urbaniak 2008: 314). W literaturze przedmiotu metoda ta występuje jako sposób tłumaczenia informacji rynkowych pochodzących od klienta na specyfikację wymagań technicznych. Dotyczy to nie tylko samej charakterystyki usługi, ale także uwarunkowań zewnętrznych (rynkowych), które muszą znaleźć swoje odzwierciedlenie wewnątrz organizacji na wszystkich etapach dostarczania usługi.

Metoda QFD jest wykorzystywana w szerokim spektrum organizacji, m.in. w działalności produkcyjnej, usługowej - w tym w szpitalach, edukacji, bankowości - oraz w projektowaniu oprogramowania komputerowego itp. Jednocześnie metoda QFD może być pomocna $\mathrm{w}$ uzyskaniu informacji na temat priorytetów, jakie z punktu widzenia organizacji oraz jej klientów stanowią okazję rynkową i/lub obszar niezagospodarowany (Łobos 2011: 112).

Przełożenie potrzeb i wymagań klienta na działania projektowe, konstrukcyjno-technologiczne/metodyczne odbywa się przy pomocy zestawu macierzy określanych mianem domu jakości (rys. 1).

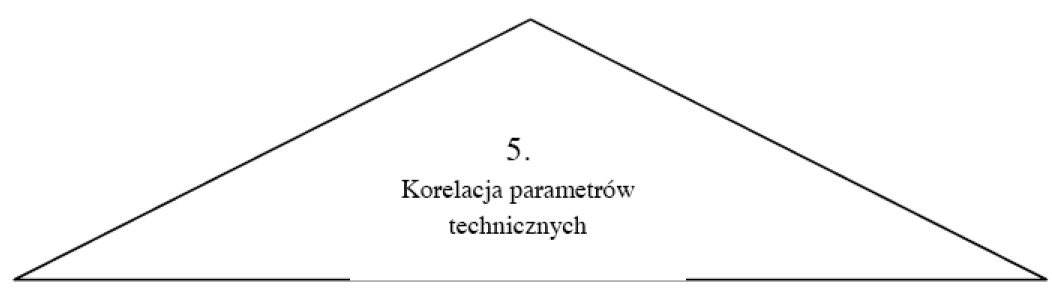

3. Parametry techniczne wyrobów, usług, cech itp.
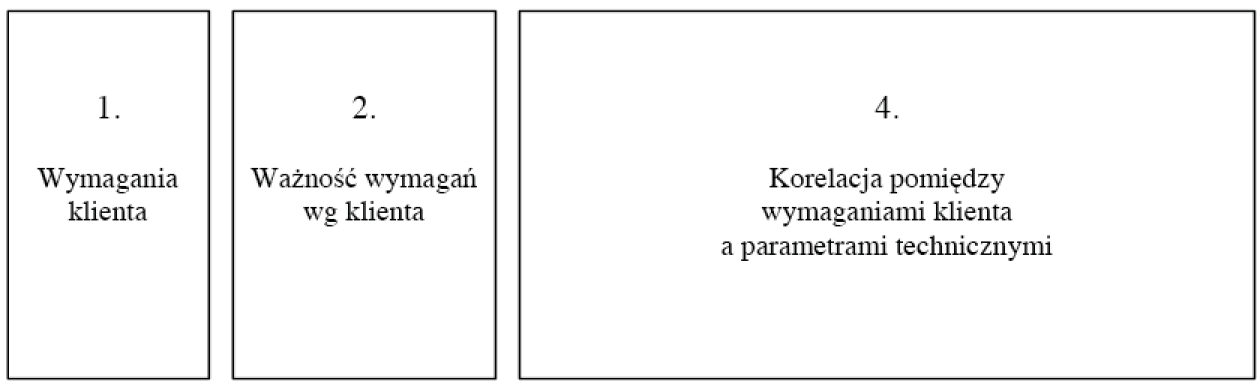

6. Ważność parametrów technicznych

Rys. 1. Dom jakości (House of Quality)

Źródło: opracowanie własne na podstawie M. Wiśniewska, House of Quality jako narzędzie planowania i rozwoju stanowiska pracy, „Problemy Jakości” 2006, nr 6, s. 20. 
W skład zobrazowanego domu jakości wchodzą:

1. Macierz specyfikująca wymagania klienta odpowiada na pytanie: jakie usługi rekreacyjne powinniśmy dostarczać? Istnieje wiele metod gromadzenia informacji od klientów na temat pożądanych przez nich cech usług. W przypadku produktów może to być ich udostępnienie użytkownikom celem przetestowania (walidacji), np. urządzenie do treningu wysiłkowego. W odniesieniu do usług informacje te gromadzi się najczęściej za pośrednictwem ankiety lub rozmów, wywiadów, grup fokusowych itp. Ważne jest zebranie jak największej ilości informacji. W przypadku usług złożonych, o wysokim stopniu trudności realizacyjnych wynikających z wymagań klientów, źródeł informacji może być nawet kilkadziesiąt.

2. Macierz stopnia ważności poszczególnych wymagań dla klientów. Odpowiada na pytanie: dlaczego te cechy, a nie inne, są istotne? Gromadząc wiedzę na temat poszczególnych wymagań, należy zebrać informacje dotyczące wag/ istotności poszczególnych cech usługi dla klienta. Przykładowo, jakie znaczenie (jaką wagę) dla klienta biura podróży, oferującego imprezę rekreacyjną, mają takie cechy, jak: kwalifikacje personelu, program zwiedzania/uczestnictwa w imprezach rekreacyjnych, opieka trenera, liczba posiłków, bezpieczeństwo podróży, zaplecze socjalne, wizerunek biura itp.? Klienci w ankietach podają zaproponowane $\mathrm{w}$ odpowiedniej skali behawioralnej wagi dla poszczególnych cech usługi, na podstawie których można dokonać rangowania ważności.

3. Macierz parametrów technicznych, która odpowiada na pytania, jak wykonać produkt, aby spełnić oczekiwania klienta, uwzględniając przy tym możliwości techniczne. Jest to macierz, w której projektanci, technolodzy czy metodycy w przypadku usług specyfikują wymagania techniczne względem produktu/usługi. Stanowi ona oprócz arkusza 1 i 2 podstawę szacowania wielkości zawartych w arkuszu 3.

4. Macierz współzależności dotyczących wymagań klienta i możliwości technicznych. W tej części dokonuje się estymacji tych współzależności w punktach, gdzie zbiegają się wymagania klienta ustalone na podstawie macierzy $\mathrm{nr} 1 \mathrm{i} 2$ oraz parametry techniczne wyspecyfikowane przez projektanta zawarte $w$ macierzy $n r 4$ domu jakości. Te współzależności mogą w różnym stopniu oddziaływać na siebie. W metodzie QFD przyjmuje się skalę 9-punktową, gdzie 1 to zależność nieistotna, 9 zaś silna. Przewaga zależności słabych (1) będzie oznaczała, że parametry (cechy) usługi określone przez klienta zostały spełnione w sposób niezadowalający. W przypadku wystąpienia w większości zależności silnych i średnich przyjęte przez projektanta założenia są trafne i spełniają oczekiwania klientów.

5. Macierz korelacji związków technicznych między poszczególnymi parametrami cech wyrobu/ usługi. Stanowi arkusz będący "dachem domu jakości". Służy ustaleniu współzależności między parametrami technicznymi wyspecyfikowanymi przez projektanta, znajdującymi się w arkuszu nr 5 domu jakości. Przykładowo, w odniesieniu do wycieczki rekreacyjnej ustalone przez projektanta parametry techniczne takie jak: kwalifikacje pilota, trenera, przewoźnika; punktualność; dojazd w określonym uprzednio czasie; sprawność środka transportu; 
zakres uczestnictwa w aktywnych formach rekreacji zgodny z programem itd., analizuje się w następujący sposób:

- jaki wpływ mają kwalifikacje trenera na program i zakres wycieczki?

- jaki wpływ na punktualność ma sprawność środka transportu oraz kwalifikacje pilota i przewoźnika? Współzależności oznacza się w tym arkuszu znakiem (+) wtedy, kiedy występują oraz (-), kiedy korelacja nie występuje. Wszędzie tam, gdzie występują znaki $(+)$, oznacza to, że są to miejsca/ obszary, w których możliwe jest pole ulepszeń dla proponowanych/projektowanych rozwiązań oraz że należy w związku z tym zwrócić na nie szczególną uwagę. W przypadku przewagi znaków (-) oznacza to, że nie ma możliwości doskonalenia. Nie można dokonywać dalszych usprawnień kosztem innych parametrów usługi.

6. Ważność parametrów technicznych - jest efektem skalowania wielowymiarowego (Biela 1995: 83). Szacowana jest przy zastosowaniu następującego wzoru (Bugdol, Goranczewski 2011):

$W_{j}=\sum N_{i} \times Z_{i j}$

gdzie:

$W_{j}$ - ważność parametru technicznego,

$Z_{i j}$ - współczynnik zależności między wymaganiem $i$ a parametrem j,

$N_{i}$ - współczynnik istotności/ważności wymagania $i$.

Oszacowana na podstawie powyższego wzoru ważność parametrów technicznych produktu /usługi pozwala wyszczególnić najistotniejsze (krytyczne) cechy, które mają kluczowy wpływ na jakość. Poszczególne współczynniki Wj tej macierzy wskazują, co nowego jest w produkcie/ usłudze oraz które z rozwiązań będzie decydowało o powodzeniu całości przedsięwzięcia.

W praktyce istnieje kilka form macierzy QFD. W przypadku produktów możliwe jest porównanie parametrów technicznych konkurencji z parametrami produktu firmy projektującej wyrób. Dla przykładu, projektant telewizora może porównywać parametry techniczne telewizorów różnych producentów. W tym celu pod arkuszem nr 6 macierzy QFD tworzy się arkusz nr 7 o nazwie: Ocena wyrobów konkurencyjnych. W przypadku usług sprawa jest bardziej skomplikowana, ponieważ trudno porównywać je w czasie rzeczywistym. W odniesieniu do projektowania nowej usługi porównanie jest niemożliwe. W sytuacji modyfikacji istniejącej usługi możliwe jest gromadzenie informacji w zakresie usług konkurencji poprzez takie techniki jak:

- informacje oraz analizy pochodzące ze źródeł internetowych,

- opinie usługobiorców,

- $\quad$ mystery shoping itp.

Jeżeli kontinuum produkt-usługa zawiera dużą liczbę komponentów materialnych, możliwe jest porównywanie usług, np. usługi hotelarskiej. Niektóre macierze wyposaża się także w arkusz określający wskaźniki technicznej trudności wykonania, przy czym dotyczy to głównie produktów. W tym celu projektanci na odpowiedniej skali określają te wskaźniki, najczęściej w skali od 1 do 10.

W praktyce istnieje szereg modyfikacji metody QFD. Przyczyną tej wielości form jest:

- $\quad$ konieczność dostosowywania metody do indywidualnych potrzeb użytkowników,

- wzrost złożoności produktów/ usług oraz

- konieczność systematycznego ich ulepszania.

Obecne kierunki zmian w modyfikacji macierzy QFD przebiegają następująco (Ćwiklicki, Obora 2008): 
1. Uszczegółowienie i wzbogacenie procedury postępowania. Dotyczy to głównie procesu tworzenia wartości dla klienta, począwszy od zamówienia, a skończywszy na dostawie oraz usługach posprzedażowych. W tym ujęciu w metodzie QFD uwzględnia się także parametry funkcjonalne, takie jak: wizerunek, analiza konkurencji, segmentacja klientów, hierarchizacja potrzeb itp.

2. Usprawnianie samej macierzy (np. liczby arkuszy czy kryteriów odniesienia), a także tworzenia tzw. macierzy macierzy, gdzie osobne macierze tworzy się między innymi dla projektowania marketingowego, projektowania systemu i podsystemów oraz projektowania szczegółowych elementów (Wolniak 2003: 17).

Celem zastosowania tak rozbudowanego narzędzia, obejmującego ogółem 30 macierzy, jest uwzględnienie wszystkich aspektów tworzenia, projektowania i realizacji produktu/usługi dla uzyskania kompleksu korzyści w takich obszarach, jak organizacja, finanse, ekonomika firmy, produkcja, realizacja (w przypadku usług), środowisko pracy sprzyjające jakości itp. W usługach rekreacyjnych nie ma potrzeby zastosowania tak szczegółowego narzędzia. Ze swojej natury usługi rekreacyjne są na tyle proste, że $w$ zupełności wystarcza metoda QFD w swojej klasycznej (wyjściowej) postaci.

Podstawowe korzyści, jakie można uzyskać ze stosowania metody QFD, są następujące:

1. udrożnienie i upowszechnienie w organizacji informacji nt. wymagań klienta względem produktu lub usługi,

2. konieczność współpracy służb rynkowych gromadzących informacje na temat oczekiwań klienta z komórkami technicznymi weryfikującymi wymagania pod kątem technicznym,

3. usprawnienie prac projektowych, w wyniku czego zwiększa się ich produktywność.

\section{Projektowanie wybranej usługi rekreacyjnej z zastosowaniem metody QFD}

W niniejszym rozdziale zawarto praktyczny przykład zastosowania metody QFD w projektowaniu usługi rekreacyjnej, jaką jest nauka jazdy na nartach. Zgodnie z procedurą postępowania projektowanie usługi odbywa się w sposób następujący:

I Identyfikacja usługi.

II Określenie atrybutów klienta, a więc odpowiednio uszeregowanych zgodnie z wymaganiami, które odpowiadają na pytanie, jakie cechy powinna posiadać usługa (tab. 1).

Tabela 1. Określenie atrybutów klienta w zakresie nauki jazdy na nartach

\begin{tabular}{|c|c|c|}
\hline $\begin{array}{c}\text { Atrybuty w zakresie } \\
\text { formy zajęć }\end{array}$ & $\begin{array}{c}\text { Atrybuty } \\
\text { związane z jednostkami } \\
\text { szkolącymi }\end{array}$ & Pozostałe atrybuty \\
\hline czas trwania nauki & bezpieczeństwo zajęć & cena usługi \\
\hline program zajęć & wizerunek firmy & forma płatności \\
\hline dostępność instruktora & $\begin{array}{c}\text { indywidualne podejście } \\
\text { do klienta }\end{array}$ & wyposażenie, sprzęt \\
\hline segmentacja klientów & kwalifikacje instruktorów & dodatkowe materiały \\
\hline dodatkowe usługi & warunki rezygnacji & warunki terenowe \\
\hline
\end{tabular}

Źródło: opracowanie własne 
III Kolejny krok w procedurze to sporządzenie ankiety, rozdanej klientom - w opisywanym przypadku piętnastu osobom - w celu wpisania przez nich własnej oceny, opartej na wcześniej ustalonych atrybutach klienta. Respondenci tak oceniają poszczególne cechy, aby w sumie dawały zawsze 100 punktów. Poglądowe zestawienie oceny atrybutów klienta przedstawia poniższa tabela (tab. 2).
IV Uzyskane przykładowe wyniki przeprowadzonej ankiety w sposób poglądowy zaprezentowano $w$ tabeli 3 .

$\checkmark$ Następny etap w realizacji projektu to określenie wagi atrybutów klienta, na podstawie uzyskanych wyników ankiety. W efekcie analizy ważności wymagań klienta poszczególnym atrybutom przypisuje się określony wskaźnik ważności (W). Atrybut, który wg osób wypełniających ankietę

Tabela 2. Poglądowe zestawienie oceny atrybutów klienta

\begin{tabular}{|c|c|}
\hline Atrybuty klienta & Ocena \\
\hline czas trwania nauki & \\
\hline program zajęć & \\
\hline …………........ & \\
\hline 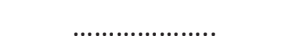 & \\
\hline dodatkowe materiały & \\
\hline warunki terenowe & \\
\hline Razem & 100 punktów \\
\hline
\end{tabular}

Źródło: opracowanie własne

Tabela 3. Zestawienie wyników przeprowadzonej ankiety

\begin{tabular}{|c|c|c|c|c|c|c|c|c|c|c|c|c|c|c|c|c|c|}
\hline Lp. & $\begin{array}{c}\text { Atry- } \\
\text { buty } \\
\text { klienta } \\
\text { /numer } \\
\text { klienta }\end{array}$ & 1 & 2 & 3 & 4 & 5 & 6 & 7 & 8 & 9 & 10 & 11 & 12 & 13 & 14 & 15 & \\
\hline 1 & $\begin{array}{c}\text { czas } \\
\text { trwania } \\
\text { nauki }\end{array}$ & 12 & 6 & 10 & 10 & 12 & 2 & & 4 & 1 & 2 & & & 1 & 2 & & 62 \\
\hline 2 & $\begin{array}{c}\text { program } \\
\text { zajęć }\end{array}$ & 8 & & 1 & 12 & 1 & 2 & 1 & 2 & 1 & 3 & 12 & & 1 & 2 & 2 & 48 \\
\hline$\ldots$ & $\ldots$. & $\ldots$ & $\ldots$ & $\ldots$ & $\ldots$ & $\ldots$ & $\ldots$ & $\ldots$ & $\ldots$ & $\ldots$ & $\ldots$ & $\ldots$ & $\ldots$ & $\ldots$ & $\ldots$ & $\ldots$ & $\ldots$ \\
\hline$\ldots$ & $\ldots .$. & $\ldots$ & $\ldots$ & $\ldots$ & $\ldots$ & $\ldots$ & $\ldots$ & $\ldots$ & $\ldots$ & $\ldots$ & $\ldots$ & $\ldots$ & $\ldots$ & $\ldots$ & $\ldots$ & $\ldots$ & $\ldots$ \\
\hline 14 & $\begin{array}{c}\text { dodat- } \\
\text { kowe } \\
\text { mate- } \\
\text { riały }\end{array}$ & 6 & & 6 & 3 & & 2 & 12 & & 0 & 2 & 8 & & 1 & & 4 & 44 \\
\hline 15 & $\begin{array}{c}\text { warunki } \\
\text { tere- } \\
\text { nowe }\end{array}$ & 8 & 6 & 8 & 2 & 16 & 4 & 12 & 12 & 2 & 27 & & 25 & 26 & 2 & & 150 \\
\hline & $\begin{array}{c}\text { Razem } \\
\text { Razem }\end{array}$ & 100 & 100 & 100 & 100 & 100 & 100 & 100 & 100 & 100 & 100 & 100 & 100 & 100 & 100 & 100 & 1500 \\
\hline
\end{tabular}

Źródło: opracowanie własne 
Tabela 4. Zestawienie wag atrybutów klienta

\begin{tabular}{|c|c|c|}
\hline Atrybut klienta & Suma punktów & Waga \\
\hline cena usługi & 333 & 5 \\
\hline indywidualne podejście do klienta & 216 & 5 \\
\hline warunki terenowe & 150 & 5 \\
\hline bezpieczeństwo zajęć & 110 & 4 \\
\hline dodatkowe usługi & 98 & 4 \\
\hline wizerunek firmy & 84 & 4 \\
\hline wyposażenie, sprzęt & 72 & 3 \\
\hline kwalifikacje instruktorów & 68 & 3 \\
\hline czas trwania nauki & 62 & 3 \\
\hline segmentacja klientów & 61 & 2 \\
\hline forma płatności & 59 & 2 \\
\hline dostępność godzin & 58 & 2 \\
\hline program zajęć & 48 & 1 \\
\hline dodatkowe materiały & 44 & 1 \\
\hline warunki rezygnacji & 37 & \\
\hline
\end{tabular}

Źródło: opracowanie własne

miał najwięcej punktów, otrzymał największą wagę 5, natomiast atrybut o najmniejszej liczbie punktów, otrzymał wagę 1 . Wyniki uzyskanych wag atrybutów klienta przedstawiono w tabeli 4.

VI Kolejnym etapem w procedurze jest określenie atrybutów technicznych usługi. Parametry techniczne muszą być tak dobrane, aby usługa spełniała wymagania klienta. Mogą mieć one charakter maksymanty $([+]$ zwiększenie wartości spowoduje lepsze spełnienei wymagań usługi), nominanty $([*]$ jest to wartość opymalna) bądź minimanty ([-] zmiejszenie wartości spodowuje lepsze spelnienie wymagań usługi) (pkt VIII).

VII Po wyznaczeniu atrybutów technicznych należy zbadać związki

Tabela nr 5. Atrybuty techniczne usługi określone przez projektanta

\begin{tabular}{|c|c|}
\hline \multicolumn{2}{|c|}{ Atrybuty techniczne } \\
\hline aspekty jakościowe $(+)$ & przedział wiekowy uczestników $(-)$ \\
\hline adekwatność ceny do proponowanych usług $(-)$ & kwalifikacje personelu $(*)$ \\
\hline punktualność rozpoczęcia zajęć $\left({ }^{*}\right)$ & odpowiednie warunki terenowe $(+)$ \\
\hline odpowiednie wyposażenie $(+)$ & profesjonalne prowadzenie zajęć $(+)$ \\
\hline marka firmy $(+)$ & odbycie zajęć zgodnie z programem $(*)$ \\
\hline
\end{tabular}


zachodzące między nimi i na tej podstawie wypełnić dach domu jakości.

VIII Następnie należy wypełnić poszczególne pola macierzy umownie nazywane pokojami domu jakości. Parametry techniczne powinny być tak dobrane, aby usługa spełniała wymagania klienta. Te współzależności mogą w różnym stopniu oddziaływać na siebie i przybierać postać:

- zależność silna - oznaczana jako 9,

- zależność średnia - pośrednia, oznaczona jako 3 ,

- zależność nieistotna - oznaczona jako 1.

IX Kolejnym etapem w procedurze jest obliczenie ważności atrybutów technicznych, wg wcześniej wskazanego wzoru (wzór 1).

W efekcie zaprezentowanej powyżej procedury powstaje dom jakości dla projektowanej usługi - nauki jazdy na nartach (schemat 2).

X. Koniec procedury postępowania to sformułowanie wniosków. $W$ analizowanym przykładzie wyniki ankiet przeprowadzonych na grupie 15 osób wykazują, że klienci przy wyborze oferty kierują się przede wszystkim ceną usługi, indywidualnym podejściem do nich samych, oraz warunkami terenowymi. Najistotniejszymi parametrami technicznymi w projektowaniu nowej usługi są przede wszystkim: jakość usługi, profesjonalizm zajęć, właściwe warunki terenowe oraz kwalifikacje oraz uprawnienia personelu. Połączenie przeprowadzonych badań z metodą QFD pozwoli opracować usługę zgodną z aktualnymi oczekiwaniami konsumentów.

\section{Bibliografia}

Biela A. (1995), Skalowanie wielowymiarowe w analizach ekonomicznych i behawioralnych, Lublin, Norbertinum.

\section{Zakończenie}

Zaprezentowany w niniejszym artykule przykład wykorzystania metody QFD dowodzi, że stanowi ona użyteczne narzędzie również w usługach rekreacyjnych. Pozwala uwzględnić wymagania klienta już na etapie projektowania, co zdecydowanie ogranicza możliwość wystąpienia usługi niezgodnej. Poprawia bezpieczeństwo świadczenia usługi, realizowanej w czasie rzeczywistym. Metoda QFD to sposób transformacji wiedzy i informacji rynkowych wyrażanych językiem konsumentów (klientów) na język i terminologię techniczną, używaną przez projektantów, konstruktorów, technologów czy metodyków w przypadku usług. Przeprowadzenie procedury QFD jest przedsięwzięciem pracochłonnym, jednak $w$ efekcie niewątpliwie korzystnym. Metoda ma bowiem wiele zalet i korzyści, wśród których wyszczególnić można:

- prostotę,

- uwzględnienie wymagań klienta,

- stałą poprawę i doskonalenie jakości usługi,

- lepsze planowanie i nadzorowanie kosztów jakości,

- możliwość inspiracji odpowiednich służb w organizacji za pośrednictwem głosu klienta do prowadzenia działalności badawczo-rozwojowej i innowacyjnej,

- poznawanie własnych zalet i słabości w stosunku do konkurencji,

- skrócenie czasu trwania cyklu rozwoju usługi.

Bugdol M., Goranczewski B. (2011), Projakościowe usprawnianie organizacji oparte na procesach. Koncepcje, metody, narzędzia, Oświęcim, PWSZ. 


\begin{tabular}{|c|c|c|c|c|c|c|c|c|c|c|c|}
\hline & $\frac{3}{3}$ & 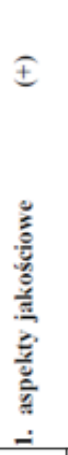 & 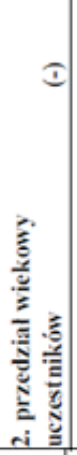 & 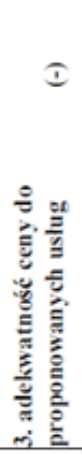 & 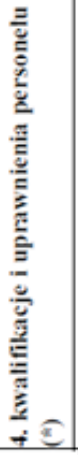 & 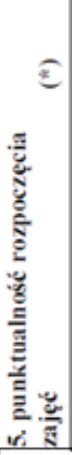 & 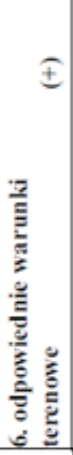 & 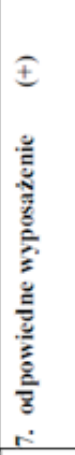 & 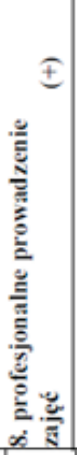 & 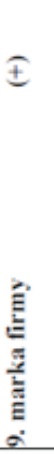 & 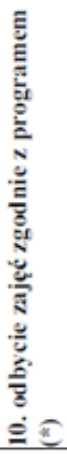 \\
\hline 1. czas trwania nauki & 3 & 1 & 3 & & & 9 & & & 1 & & 9 \\
\hline 2. program zajẹć & 1 & 9 & 3 & 9 & & 9 & & 3 & 9 & & 9 \\
\hline 3. dostẹpność godzin & 2 & 1 & & & & & & & & & \\
\hline 4. segmentacja klientów & 2 & 3 & 9 & & 3 & & & 1 & 9 & 1 & \\
\hline 5. dodatkowe uslugi & 4 & & & & & & & & & 1 & \\
\hline 6. bezpieczeństwo zajęć & 4 & 9 & 9 & 1 & 9 & 3 & 3 & 1 & 9 & & 1 \\
\hline 7. wizerunek firmy & 4 & 3 & & & 9 & 3 & 9 & 3 & 9 & 3 & 1 \\
\hline $\begin{array}{l}\text { 8. indywidualne podejście } \\
\text { do klienta }\end{array}$ & 5 & 9 & & & 3 & & & & 3 & 9 & \\
\hline 9. kwalifikacje instruktorów & 3 & 9 & 3 & 1 & 9 & & & & 9 & 3 & 3 \\
\hline 10. warunki rezygnacji & 1 & 1 & & & & & & 1 & & & \\
\hline 11. cena uslugi & 5 & 1 & & 9 & 1 & & 9 & 9 & 3 & 3 & \\
\hline 12. forma platności & 2 & 1 & & & & & & & & & \\
\hline 13. wyposażenie, sprzẹt & 3 & 3 & 9 & 3 & 3 & & & 9 & & 1 & \\
\hline 14. dodatkowe materialy & 1 & 3 & 1 & & & & & 3 & & & \\
\hline 15. warunki terenowe & 5 & 3 & & & & & 9 & 1 & & 1 & \\
\hline \multicolumn{2}{|l|}{$\begin{array}{l}\text { WAŻNOSC PARANIETRÓW } \\
\text { TECHNICZNYCH }\end{array}$} & 175 & 103 & 70 & 134 & 60 & 138 & 102 & 159 & 95 & 53 \\
\hline \multicolumn{2}{|l|}{$\begin{array}{l}\text { WAŻNOŚĆ PARANIETRÓW } \\
\text { TECHNICZNYCH W \% }\end{array}$} & 16,1 & 9,5 & 6,4 & 12,3 & 5,5 & 12,7 & 9,4 & 14,6 & 8,7 & 4,9 \\
\hline
\end{tabular}

Schemat 2. Quality of House dla projektowanej usługi

Źródło: opracowanie na podstawie M. Bugdol, B. Goranczewski, Projakościowe usprawnianie organizacji oparte na procesach. Koncepcje, metody, narzędzia, PWSZ, Oświęcim, s. 34 
Czakon W. (2013), Zastosowanie studium przypadku w badaniach nauk o zarzqdzaniu [w:] Podstawy metodologii badań w naukach o zarzq̨dzaniu, red. W. Czakon, Warszawa, Wolters Kluwer, s. 92-113.

Czubała A. (2006), Usługi w gospodarce [w:] Marketing usług, red. A. Czubała, A. Jonas, T. Smoleń, J. Wiktor, Kraków, Wolters Kluwer.

Ćwiklicki M., Obora H. (2008), Ewolucja i dyfuzja metody QFD, „Problemy Jakości" nr 3, s. 4-7.

Ćwiklicki M., Obora H. (2008), Kierunki rozwinięcia metody QFD, „Problemy Jakości", nr 4, s. 10-13.

Daszkowska M. (1998), Usługi. Produkcja, rynek, marketing, Warszawa, PWN.

Goranczewski B., Puciato D. (2010), TQM a jakość życia, „Problemy Jakości" , nr 6, s. 4-9.

Goranczewski B., Szeliga-Kowalczyk A. (2015), Jakość usług turystycznych i rekreacyjnych. Ujęcie holistyczne, Warszawa, CeDeWu.
Gospodarek J. (2008), Prawo w turystyce i rekreacji, Warszawa, Difin.

Kotler P. (1996), Marketing, Warszawa, Gethner \& Ska.

Łobos K. (2011), Organizacje - proste idee, zasady, narzędzia, Poznań, WSB.

Maciąg J. (2011), System zarzadzania jakościq usług. Zasady i metody (na przykładzie usług turystycznych i rekreacyjnych), Katowice, AWF.

Skrzypek E. (2009), Zarzq̨dzanie kapitałem relacyjnym $w$ organizacji [w:] Jakość i komunikacja w zarzq̨dzaniu, red. T. Wawak, Kraków, UJ.

Urbaniak M. (2008), Zarzqdzanie jakościq. Teoria i praktyka, Warszawa, Difin.

Wiśniewska M. (2006), House of Quality jako narzędzie planowania i rozwoju stanowiska pracy, „Problemy Jakości” nr 6, s. 20-26.

Wolniak R. (2003), Koncepcja 30-macierzowego rozwinięcia metody QFD, „Problemy Jakości” nr 9, s. 17-29.

Zymonik Z., Wąsińska A. (2007), QFD metoda sterowania jakościq przez klienta, „Problemy Jakości” nr 3.

\title{
Applicability of QFD Method to the Design of Recreation Services
}

\begin{abstract}
The purpose of the article is to present the applicability of QFD method to the design of recreation services. QFD method is an excellent tool for the design and preparation of service in the way that avoids inconsistency during its delivery, and it takes the customer's requirements into account. Using this method allows to obtain the customer's opinion before the service is provided, thereby allowing service providers to protect themselves from possible dissatisfaction and, consequently, claims and loss of the customer. The analysis of the subject literature and description of the case study were used as a research method. So far, QFD method has been used mainly in the design of products and production processes. The possibilities of its application in services are very wide, and its usefulness in terms of potential benefits is
\end{abstract}


very high. The first section of the article presents the specificity of recreation services, its characteristics and determinants of proper preparation, as well as the basic forms of providing these services. The second section concerns the characteristics and a detailed description of QFD method. The third one presents a practical example of using this method in the design of the selected recreation service.

Keywords: recreation, service, quality, design, customer, improvement, quality function, QFD 
